\title{
Examines the Misconceptions of Students Biology Education: Health Biotechnology
}

Hilarius Jago Duda ${ }^{1}$, Dwi Cahyadi Wibowo ${ }^{2}$, F. Rahayu Esti Wahyuni ${ }^{3}$, Antonius Edy Setyawan ${ }^{4}$, Muhammad Rian Subekti ${ }^{5}$

1 High School of Teacher and Education (STKIP) Persada Khatulistiwa, Biology Education Study Program, JL. Pertamina-Sengkuang, Sintang, West Kalimantan, Indonesia, hilariusjagod@yahoo.com

2 High School of Teacher and Education (STKIP) Persada Khatulistiwa, Elementary School Teacher Education Study Program, JL. Pertamina-Sengkuang, Sintang, West Kalimantan, Indonesia. dwicahyadiwibowo@gmail.com

3 High School of Teacher and Education (STKIP) Persada Khatulistiwa, Biology Education Study Program, JL. Pertamina-Sengkuang, Sintang, West Kalimantan, Indonesia, estipandi84@gmail.com

4 High School of Teacher and Education (STKIP) Persada Khatulistiwa, Computer Education Study Program, JL. Pertamina-Sengkuang, Sintang, West Kalimantan, Indonesia, edysetyawan200286@gmail.com

5 High School of Teacher and Education (STKIP) Persada Khatulistiwa, Elementary School Teacher Education Study Program, JL. Pertamina-Sengkuang, Sintang, West Kalimantan, Indonesia.m.rian.subekti@gmail.com

Annotation. This research is used to identify and find out the misconceptions (factors misconceptions and given solutions) at biology education students on the concept of health biotechnology. By using CRI (Certainty of Response Index), interview data and theoretical studies. The findings show that quite a lot of student have misconceptions. The factors that cause students to experience misconceptions are abstract concepts and information from print media, internet, teaching staff, and colleagues.

Keywords: misconceptions, students, health biotechnology, Indonesia.

\section{Introduction}

Health biotechnology is a field that has prominent development because it has high commercial value. For example, acetosal, molecular weight 180, prepared by synthesis, daily dose of $3 \mathrm{~g}$, is worth one penny. The scope of health biotechnology includes the use of living cells, namely microorganisms, tissue cultures, or enzymes to produce a drug, treatment, or diagnostic tool. Biotechnology in the medical field is used for various purposes, including the manufacture of monoclonal antibodies, human gene therapy, drug 
manufacturing, and vaccines. Health biotechnology has developed and modified vaccines to obtain more effective vaccines through recombinant DNA and genetic engineering. Diseases caused by viruses cannot be treated, so prevention needs to be done by using vaccines. For example, the covid-19 virus vaccine is currently being discussed. Many people still doubt using the covid-19 vaccine, actually vaccines having a very important function for individual health. This can be caused by limited knowledge or misconceptions in the community about information vaccines.

Seeing the importance of health biotechnology in human life in this modern era, it needs to be studied properly and correctly in learning at school or college. In higher education, for example, in the biology education study program, there is a biotechnology course and one part that is learned from this course is health biotechnology. The important point is what there are misconceptions in these students, so to find out the misconceptions that occur in students, it is necessary to test the understanding of these concepts in health biotechnology. Because of the correct understanding of the concept and there are no misconceptions of the course students can apply it properly and correctly in everyday life and can also pass on the correct knowledge to their future generations, moreover, these students are prospective teacher students. In this research, in addition to disclosing misconceptions and the causes of misconceptions, solutions are also sought to overcome them. One of the things that is interesting is to express misconceptions and students' conceptual understanding by conducting diagnostic tests and interviews so that it can reveal students who experience misconceptions, do not understand concepts, and who understand concepts. The research reveals specifically about misconceptions of biology education students on the material health biotechnology which includes antibodies and vaccines.

Misconceptions are conceptions (cognitive structures) that are firmly attached to the minds of students which actually deviate from the conceptions put forward by experts. This conception deviation can mislead in understanding natural phenomena and carrying out scientific explanations (Hammer, 1996). Misconceptions can occur when students are trying to form knowledge by translating new experiences in the form of initial conceptions (Gardner, 2009). According to several studies by Nusantari (2011); Saehana \& Kasim (2011); \& Suniati et al. (2013) that misconception is a major problem in education in various learning materials, including biology. Because its existence can hinder the assimilation of students' new knowledge. This problem occurs at various levels of education, from elementary school to university level. The results of previous studies reinforce the high misconceptions in various materials in Indonesia.

Several research results show misconceptions in a number of biological concepts including the concept of human body structure, evolution, genetics, and biotechnology. Murni (2013) also found misconceptions on the concept of cell structure and function, plant structure, and coordination systems. The concept of the structure and function of plant tissue is one of those materials that is difficult to understand because of the 
many abstract scientific terms and many concepts that must be memorized. The results of research by Queloz et al. (2017) show that many students are attracted by popular misconceptions about questions related to evolutionary processes, interactions, and molecular structure. In some cases, this appears to be due to a failure to emphasize the relevance of knowledge from physical and chemical instructions to biological contexts.

Susanti (2018) research results suggest that there is still a misunderstanding of the concept of photosynthesis, namely a misunderstanding of the concept of the place and time of photosynthesis in plants, the role of the sun in photosynthesis, energy needed in the form of photosynthesis, and the role of photosynthesis in plants. In addition, there is also a misunderstanding of the concept of respiration, namely about the place of respiration in plants, the gas needed for plant respiration, and the time for plants to respire, as well as the $\mathrm{CO}_{2}$ and $\mathrm{O}_{2}$ cycles that occur in nature.

There is also another study that revealed a misconception of using CRI on plant tissue material in biology education students at a university in Surakarta, Indonesia, as many as $26.34 \%$ experienced a misconception. In addition, misconceptions are not affected by the academic category of students, this is indicated by the highest level of misconceptions in the medium category students at $52.55 \%$, followed by the upper category students $28.37 \%$ and the last category students under the category 19.07\% (Puspitasari, 2019). There are various studies showing that students' misconceptions have a considerable influence on learning about basic science concepts and advanced concepts. Therefore, identification of students' misconceptions is very important for effective lesson planning and correcting students' difficulties in understanding science concepts (Kirbulut, 2014; Artdej, 2010; and Ayas et al., 2010).

From the results of research about misconceptions on the above biological themes that occur in Indonesia, it can be seen that still many students experience misconceptions on biology themes. Therefore, researchers are interested in examining in depth the misconceptions of students on the concept of health biotechnology, especially in antibody and vaccine material. In this study, student misconceptions were identified using the CRI (Certainty of Response Index). This method is used by Saleem Hasan, Diola Bagayoko, and Ella L. Kelley to distinguish between students who understand concepts, do not understand concepts, and those who experience misconceptions. Based on the results of these studies, they proved that the CRI (Certainty of Response Index) was effective in diagnosing students who did not understand the concept and students who experienced misconceptions (Hasan et al., 1999). This is supported by the results of research conducted by Purba and Depari (2008) which show that the use of CRI can differentiate between students who experience misconceptions and students who lack knowledge. After analysing using CRI, it was followed by interviews with students who experienced misconceptions and the results of the interview were described. From this misconception data, the researcher conducted a further theoretical study to find a solution to overcome the misconception in accordance with the factors causing the misconception. 
From the above problems, the formulation of the problem in the study can be described, namely how the misconceptions experienced by biology education students on the concept of health biotechnology (especially in antibodies and vaccines) and what factors cause these misconceptions and the solutions given to overcome the misconceptions. The objectives of this study are first, to identify, examine and determine the students' misconceptions in health biotechnology (especially in antibodies and vaccines). Second, to identify information that does not know the concept, know the concept, and students' misconceptions from each indicator of the material presented. Third, it can be concluded how much the value of not knowing the concept, knowing the concept, and the overall misconception on the concept of health biotechnology (especially in antibodies and vaccines). Fourth, it can determine the factors that cause misconceptions in the concept of health biotechnology (especially in antibodies and vaccines). Fifth, it can provide an overview of solutions, overcome, and prevent misconceptions in students.

\section{Research Methodology}

\section{General Background}

The research approach used in the study is qualitative. This research method uses a qualitative descriptive method that does not provide treatment, manipulation, or change the independent variables, but describes a condition as it is. According to Muri (2017, p. 44) qualitative research is to reveal a situation or object in its context, find meaning, or a deep understanding of a problem at hand. Descriptive research focuses on solving problems in the present in addition to describing situations or events accurately. This study uses a CRI (Certainty of Response Index) format with 4 stages of research, namely data collection, data presentation, data reduction, and drawing conclusions.

\section{Sample}

The population in this study were all biology education students STKIP Persada Khatulistiwa Sintang West Kalimantan Indonesia who had taken biotechnology courses. The sample used was 29 biology education students. The sample was selected by purposive sampling technique which in accordance with the aims and needs of the researcher.

\section{Instrument and Procedures}

Instruments of data collection were carried out by means of a multiple-choice diagnostic test with a CRI format and interviews with students who had misconceptions about the concept of health biotechnology. In each multiple-choice instrument question, students are asked to choose the answer that is considered the most correct and followed by checking the confidence table. Respondents must write a confidence index for the 
answer or a CRI consisting of numbers 1-5 (Hasan et al., 1999). The number of multiple choice questions in the CRI format is 18 numbers covering the three sub-materials of health biotechnology. Furthermore, interviews were conducted with students who had misconceptions to find out the concepts of health biotechnology who had misconceptions and to find out the factors causing the misconceptions. After obtaining the interview data, it is continued by examining the supporting theories to overcome the factors causing the misconception.

\section{Data Analysis}

In this study, the data analysis of student misconceptions was carried out in accordance with the CRI analysis developed by Hasan et al. (1999). CRI is a measure of the level of confidence or certainty of respondents in answering each question given. A low CRI indicates a lack of conceptual confidence in the respondent in answering a question, whereas a high CRI reflects a high confidence and certainty in the respondent's concept. The developed CRI has six scales, namely $0-5$ equipped with the criteria, as shown in Table 1.

\section{Table 1}

CRI and Its Criteria

\begin{tabular}{cl}
\hline CRI & \multicolumn{1}{c}{ Criteria } \\
\hline 0 & (Totally guessed answer) \\
1 & (Almost guess) \\
2 & (Not Sure) \\
3 & (Sure) \\
4 & (Almost certain) \\
5 & (Certain) \\
\hline
\end{tabular}

To clarify the scoring of each question, the following will explain the provisions for distinguishing between knowing concepts, misconceptions, and not knowing concepts for individual respondents.

\section{Table 2}

CRI Analysis Based on Answer Criteria

\begin{tabular}{|c|c|c|}
\hline $\begin{array}{l}\text { Criteria } \\
\text { The answer }\end{array}$ & $\begin{array}{c}\text { Low CRI } \\
(\mathrm{CRI}<2,5)\end{array}$ & $\begin{array}{l}\text { High CRI } \\
(\mathrm{CRI}>2,5)\end{array}$ \\
\hline The answer & Correct answer but CRI & Correct answer and CRI \\
\hline Correct & Low, do not know the concept (lucky guess) & High, mastering concept with well \\
\hline $\begin{array}{l}\text { The answer } \\
\text { False }\end{array}$ & $\begin{array}{l}\text { Incorrect answer and CRI Low, do not } \\
\text { know the concept }\end{array}$ & $\begin{array}{l}\text { Wrong answer but CRI } \\
\text { High, misconceptions } \\
\text { Occur }\end{array}$ \\
\hline
\end{tabular}


Based on Table 2, it can be explained that if the student's answer is correct but the CRI is low, this means that they do not know the concept (lucky guess). If the student's answer is correct and the CRI is high, it means mastering the concept well (knowing the concept). If the student's answer is wrong and the CRI is low, it means that they do not know the concept, and if the student's answer is wrong but the CRI is high, it means that there is a misconception. After that, the percentage of students who know the concept, don't know the concept and misconception is calculated with the following formula:

Percentage $\mathrm{X}=\mathrm{X} / \mathrm{N}$ X $100 \%$;

Percentage $\mathrm{Y}=\mathrm{Y} / \mathrm{N} \mathrm{X} 100 \%$;

Percentage $\mathrm{Z}=\mathrm{Z} / \mathrm{N}$ X $100 \%$.

Information:

$\mathrm{X}=$ Number of students who know the concept;

$\mathrm{Y}=$ Number of students who do not know the concept;

$\mathrm{Z}=$ Number of students who are misconceptions;

$\mathrm{N}=$ Total number of students.

Furthermore, an analysis of student understanding was carried out in each subconcept by adding up the percentage of students who knew the concept, did not know the concept and the misconceptions in each sub-concept based on the confidence of the students' answers on each test question. To find out the causes of misconceptions, interviews were conducted with several students who experienced misconceptions in the three biotechnology sub-materials, namely the definition of health biotechnology, types of health biotechnology (types, techniques, stages, processes), the benefits of health biotechnology. The interview data are then described. From the interview data, the researcher examines the theory further to find solutions to overcome the misconceptions that occur in students.

\section{Results}

Based on research that has been conducted on 29 students regarding the misconceptions of biology education students in the health biotechnology subject using the CRI method, it is known that some students still experience different misconceptions in working on biotechnology questions. The following are the sub material and material indicators as well as the question numbers under study. 
Table 3

Sub-Material Indicators Studied

\begin{tabular}{cllc}
\hline $\begin{array}{c}\text { Num- } \\
\text { ber }\end{array}$ & \multicolumn{1}{c}{ Sub Material } & \multicolumn{1}{c}{ Indicator material } & $\begin{array}{c}\text { Question } \\
\text { number }\end{array}$ \\
\hline 1 & Health biotechnology & Monoclonal antibody definition & 6 \\
& definition & Definition of antibodies & 9 \\
& & Antibody dependent cellular cytotoxicity & 11 \\
& & Enzymes in antibodies & 12 \\
\hline 2 & Types of health biotechnolo- & Techniques of health biotechnology & 1 \\
& gy (types, techniques, stages,, & How to produce monoclonal antibodies & 5 \\
& processes) & Merger of tumor cells and mammalian cells & 7 \\
& & Types of monoclonal antibodies & 8 \\
& & Human papilloma virus (HPV) vaccine & 16 \\
& & DNA vaccine mechanism & 18 \\
& & Health biotechnology processes & 2 \\
& & Combination mechanism & 10 \\
& & Types of vaccines & 15 \\
\hline 3 & Health benefits of biotech & Utilization in the medical field \\
& nology & Example of developing health biotechnology & 4 \\
& & Benefits of monoclonal antibodies & 13 \\
& & Benefits of health biotechnology & 14 \\
& & Benefits of using vaccines & 17 \\
\hline
\end{tabular}

Analysing student misconceptions using CRI, namely looking at student test results by checking the answers to multiple choice test results and the CRI scale given to students, then adjusting it to the provisions to distinguish student misconceptions. Students who are said to have misconceptions are students who answer the questions wrongly, but have high confidence in the correctness of the answers by choosing the CRI 3-5 scale. Based on the results of research on the concept of health biotechnology, it was found that some students experienced knowing the concept, not knowing the concept, and misconceptions of each item number studied on the concept of health biotechnology, this can be seen in Table 4 . 
Table 4

Data on the Percentage of Knowing the Concept, not Knowing the Concept, and Student Misconceptions of Each Item on the Concept of Health Biotechnology

\begin{tabular}{|c|c|c|c|c|c|c|}
\hline No & Sub material & $\begin{array}{l}\text { Number } \\
\text { questions }\end{array}$ & $\begin{array}{l}\text { Percentage } \\
\text { Know the } \\
\text { concept }(\mathrm{X})\end{array}$ & $\begin{array}{l}\text { Percentage } \\
\text { do not know } \\
\text { the concept } \\
(Y)\end{array}$ & $\begin{array}{l}\text { Percentage } \\
\text { Misconcep- } \\
\text { tions } \\
\text { (Z) }\end{array}$ & $\begin{array}{c}\text { Average } \% \text { of } \\
\text { misconceptions } \\
\text { in each sub- } \\
\text { material }\end{array}$ \\
\hline \multirow[t]{5}{*}{1} & \multirow{5}{*}{$\begin{array}{l}\text { Health biotech- } \\
\text { nology defini- } \\
\text { tion }\end{array}$} & 6 & $48.27 \%$ & $34.48 \%$ & $17.24 \%$ & \multirow{5}{*}{$36.20 \%$} \\
\hline & & 9 & $37.93 \%$ & $6.89 \%$ & $55.17 \%$ & \\
\hline & & 11 & $17.24 \%$ & $27.58 \%$ & $55.17 \%$ & \\
\hline & & 12 & $48.27 \%$ & $34.48 \%$ & $17.24 \%$ & \\
\hline & & $\begin{array}{l}\text { Average } \\
\text { percentage }\end{array}$ & $37.93 \%$ & $25.86 \%$ & $36.20 \%$ & \\
\hline \multirow[t]{10}{*}{2} & \multirow{10}{*}{$\begin{array}{l}\text { Types of health } \\
\text { biotechnology } \\
\text { (types, techni- } \\
\text { ques, stages, pro- } \\
\text { cesses) }\end{array}$} & 1 & $31.03 \%$ & $6.89 \%$ & $62.07 \%$ & \multirow{9}{*}{$34.86 \%$} \\
\hline & & 5 & $17.24 \%$ & $27.58 \%$ & $55.17 \%$ & \\
\hline & & 7 & $41.38 \%$ & $24.14 \%$ & $34.48 \%$ & \\
\hline & & 8 & $3.45 \%$ & $75.86 \%$ & $20.68 \%$ & \\
\hline & & 16 & $48.27 \%$ & $34.48 \%$ & $17.24 \%$ & \\
\hline & & 18 & $34.48 \%$ & $34.48 \%$ & $31.03 \%$ & \\
\hline & & 2 & $24.14 \%$ & $41.38 \%$ & $34.48 \%$ & \\
\hline & & 10 & $37.93 \%$ & $44.83 \%$ & $17.24 \%$ & \\
\hline & & 15 & $34.48 \%$ & $24.14 \%$ & $41.38 \%$ & \\
\hline & & $\begin{array}{l}\text { Average } \\
\text { percentage }\end{array}$ & $30.27 \%$ & $34.86 \%$ & $34.86 \%$ & \multirow{7}{*}{$46.26 \%$} \\
\hline \multirow[t]{7}{*}{3} & Health benefits & 3 & $41.38 \%$ & $24.14 \%$ & $34.48 \%$ & \\
\hline & of biotechnology & 4 & $37.93 \%$ & $6.89 \%$ & $55.17 \%$ & \\
\hline & & 13 & $10.34 \%$ & $34.48 \%$ & $55.17 \%$ & \\
\hline & & 14 & $34.48 \%$ & $34.48 \%$ & $31 ., 03 \%$ & \\
\hline & & 17 & $10.34 \%$ & $34.48 \%$ & $55.17 \%$ & \\
\hline & & $\begin{array}{l}\text { Average } \\
\text { percentage }\end{array}$ & $26.89 \%$ & $36.89 \%$ & $46.26 \%$ & \\
\hline & & \multicolumn{4}{|c|}{ Average percentage of overall misconceptions } & $39.11 \%$ \\
\hline
\end{tabular}

The following is an example of a student's answer on a multiple choice question sheet in CRI format. In the number one and five answers students experienced a misconception where answers number one and five were wrong and students chose the criteria for sure (3) and almost very sure (4). Whereas answer number two is wrong and students choose the criteria to guess (1) this includes not knowing the theory. In answer number three it is correct but students choose not to understand (0) this includes not knowing the theory. Whereas answer number four is correct and students choose to believe (3) this is included in the knowing the theory. An example of student answers in the CRI format is presented in Figure 1. 


\section{Figure 1}

Examples of Student Answers in CRI Format

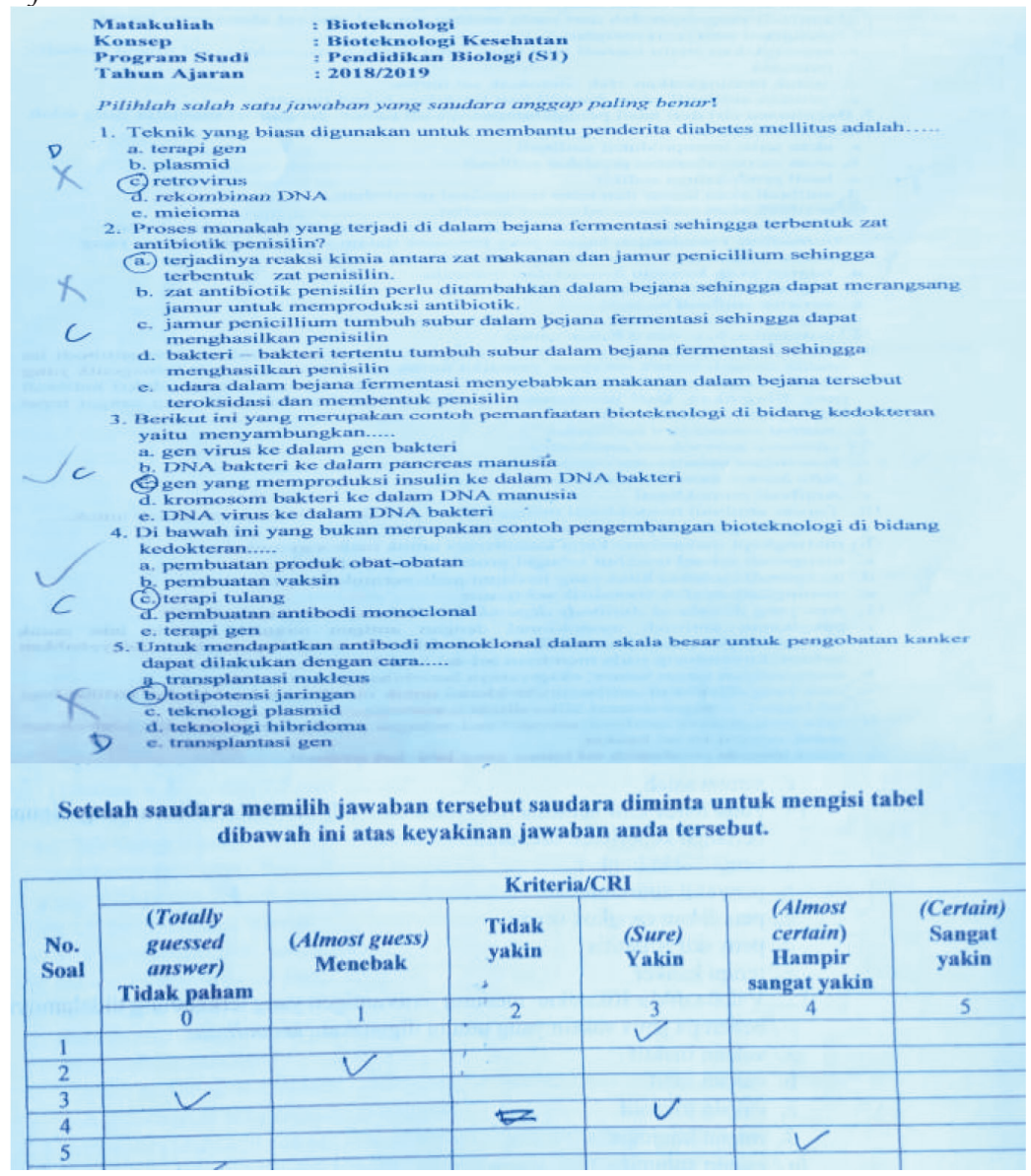

In addition to describing the misconception data for each item number from the existing question indicators. The researcher also recapitulated that overall the data knew the concept, did not know the concept, and the misconceptions of biology education students on the concept of health biotechnology. Where from these data we can see the overall results about student misconceptions on the concept of health biotechnology. For more details, the data can be seen in Table 5 .

In addition to providing multiple choice test instruments, this study revealed student misconceptions through interviews with students who experienced misconceptions from multiple choice data. The results of the interview showed that the causes of student misconceptions in the health biotechnology course included the concept of substance in health biotechnology which was always related to basic biology which was abstract, many foreign terms, difficult language, and students' unpreparedness in accepting the material presented by the lecturer. 
Table 5

The Results of the Overall Recap of the Data Know the Concept, do not Know the Concept, and Student Misconceptions on the Material of Health Biotechnology

\begin{tabular}{clccccc}
\hline $\begin{array}{c}\text { Num- } \\
\text { ber }\end{array}$ & \multicolumn{1}{c}{ Criteria } & $\begin{array}{c}\text { Number of } \\
\text { Students }\end{array}$ & $\begin{array}{c}\text { Number of } \\
\text { Questions }\end{array}$ & Score & Average & $\begin{array}{c}\text { Percent } \\
(\%)\end{array}$ \\
\hline 1 & Know the concept (X) & 29 & 18 & 160 & 9.19 & 31,70 \\
2 & Don't not know the concept (Y) & 29 & 18 & 162 & 9.43 & 32,54 \\
3 & Misconceptions (Z) & 29 & 18 & 200 & 11.31 & 39,11 \\
\hline
\end{tabular}

In addition, the learning resources used also have misconceptions, including print media such as books, printed journals, and also other social media such as the internet, teaching staff, and peers. However, the dominant qualitative data that answers the main cause of the misconception is that the health biotechnology material is difficult because it is abstract and also from misconceptions in printed media in the form of books. The results of interviews of students who experienced misconceptions on the concept of health biotechnology are presented in Table 6.

Table 6

Results of Student Interview Analysis

\begin{tabular}{|c|c|c|c|c|}
\hline $\begin{array}{l}\text { Num- } \\
\text { ber }\end{array}$ & $\begin{array}{c}\text { Health } \\
\text { Biotechnology } \\
\text { Sub-concept }\end{array}$ & Question & $\begin{array}{l}\text { Answers to misconceptions } \\
\text { from students }\end{array}$ & $\begin{array}{l}\text { Factors causing } \\
\text { misunderstanding }\end{array}$ \\
\hline 1 & $\begin{array}{l}\text { Health bio- } \\
\text { technology } \\
\text { definition }\end{array}$ & $\begin{array}{l}\text { 1. What is meant by } \\
\text { monoclonal anti- } \\
\text { body? } \\
\text { 2. What is the pur- } \\
\text { pose of using the } \\
\text { combination mech- } \\
\text { anism monoclonal } \\
\text { antibody? }\end{array}$ & $\begin{array}{l}\text { 1. Many students answered that } \\
\text { antibodies were obtained from a } \\
\text { single source or clone cells and } \\
\text { recognized several types of anti- } \\
\text { gens. (This is a misconception). } \\
\text { The real answer is: antibodies } \\
\text { obtained from a single source or } \\
\text { clone cells that recognize only } \\
\text { one type of antigen. } \\
\text { 2. Many students who answered } \\
\text { with confidence were to recog- } \\
\text { nize the typical molecules pres- } \\
\text { ent on the surface of cancer cells. } \\
\text { The real answer is to increase the } \\
\text { cytotoxic effect of tumor cells }\end{array}$ & $\begin{array}{l}\text { 1. Where did you } \\
\text { get the concept in- } \\
\text { formation? } \\
\text { The answer: books, } \\
\text { print journals, as } \\
\text { well as other social } \\
\text { media such as the } \\
\text { internet, teach- } \\
\text { ing staff, and col- } \\
\text { leagues }\end{array}$ \\
\hline
\end{tabular}




\begin{tabular}{|c|c|c|c|c|}
\hline $\begin{array}{l}\text { Num- } \\
\text { ber }\end{array}$ & $\begin{array}{c}\text { Health } \\
\text { Biotechnology } \\
\text { Sub-concept }\end{array}$ & Question & $\begin{array}{l}\text { Answers to misconceptions } \\
\text { from students }\end{array}$ & $\begin{array}{l}\text { Factors causing } \\
\text { misunderstanding }\end{array}$ \\
\hline 2 & $\begin{array}{l}\text { Types of health } \\
\text { biotechnology } \\
\text { (types, tech- } \\
\text { niques, stages, } \\
\text { processes) }\end{array}$ & $\begin{array}{l}\text { 1. How to get mono- } \\
\text { clonal antibody on a } \\
\text { large scale for cancer } \\
\text { treatment? } \\
\text { 2. One of the health } \\
\text { biotechnology tech- } \\
\text { niques commonly } \\
\text { used to help diabetes } \\
\text { mellitus sufferers is a } \\
\text { technique? } \\
\text { 3. Why are recombi- } \\
\text { nant vaccines safer } \\
\text { than vaccines that } \\
\text { contain all viral cells? } \\
4 \text {. What are the char- } \\
\text { acteristics of the } \\
\text { merging of tumor } \\
\text { cells with mamma- } \\
\text { lian cells that have } \\
\text { been replicated? }\end{array}$ & $\begin{array}{l}\text { 1. Many students answered with } \\
\text { plasmid technology, the real } \\
\text { answer is hybridoma technology } \\
\text { 2. Many students answered with } \\
\text { gene therapy that the real answer } \\
\text { is recombinant DNA. } \\
\text { 3. Many students answered } \\
\text { that the antigenic fragments } \\
\text { contained in the recombinant } \\
\text { vaccine can reproduce in the } \\
\text { recipient's body. } \\
\text { the real answer is that the an- } \\
\text { tigenic fragments contained in } \\
\text { the recombinant vaccine cannot } \\
\text { reproduce in the recipient's body } \\
\text { 4. Many students who answered } \\
\text { that antibodies would run } \\
\text { smoothly and would continue to } \\
\text { change, the real answer was that } \\
\text { they would continue to produce } \\
\text { antibodies }\end{array}$ & $\begin{array}{l}\text { 2. How do you re- } \\
\text { spond to biotech- } \\
\text { nology materials? } \\
\text { The answer: biotech- } \\
\text { nology material is } \\
\text { quite difficult be- } \\
\text { cause there is a rela- } \\
\text { tionship with basic } \\
\text { biology material that } \\
\text { is abstract, many for- } \\
\text { eign terms make it } \\
\text { difficult for students } \\
\text { to understand. }\end{array}$ \\
\hline 3 & $\begin{array}{l}\text { Health bene- } \\
\text { fits of biotech- } \\
\text { nology }\end{array}$ & $\begin{array}{l}\text { 1. Mention the } \\
\text { function of the hu- } \\
\text { man papilloma vi- } \\
\text { rus (HPV) vaccine! } \\
\text { 2. Give an exam- } \\
\text { ple of a new type of } \\
\text { monoclonal anti- } \\
\text { body that is used for } \\
\text { various purposes? }\end{array}$ & $\begin{array}{l}\text { 1. Many students who answered } \\
\text { breast cancer, the real answer is } \\
\text { cervical cancer } \\
\text { 2. Many students who answered } \\
\text { that the real answers were can- } \\
\text { cer treatment, autoimmune dis- } \\
\text { ease, organ transplant rejection, } \\
\text { and cancer therapy or others. }\end{array}$ & \\
\hline
\end{tabular}

From the interview data, the researcher continued to study the theory of solutions to overcome student misconceptions that occurred in the concept of health biotechnology. The solution given is adjusted to the factors causing the misconception. Solutions in addressing student misconceptions that occur in the material are presented in Table 7. 
Table 7

Solutions to Overcome and Prevent Misconceptions that Occur in Students

\begin{tabular}{|c|c|c|}
\hline $\begin{array}{c}\text { Num- } \\
\text { ber }\end{array}$ & $\begin{array}{l}\text { Factors that cause } \\
\text { misconception }\end{array}$ & Solution given \\
\hline 1. & $\begin{array}{l}\text { Teaching staff: teachers and } \\
\text { lecturers }\end{array}$ & $\begin{array}{l}\text { To overcome the misconceptions that come from the } \\
\text { teacher/lecturer, in learning the teacher should be able to } \\
\text { use a variety of learning strategies or methods so that they } \\
\text { can empower all the potential that students have. Learning } \\
\text { should also be able to train thinking skills and process } \\
\text { skills, for example through practicum, problem-based } \\
\text { learning, inquiry, and feedback learning so that students } \\
\text { can learn deeply about the concepts being taught. }\end{array}$ \\
\hline 2. & $\begin{array}{l}\text { Learning resources used in } \\
\text { schools or colleges }\end{array}$ & $\begin{array}{l}\text { We recommend that the learning resources used are } \\
\text { sources that are trusted and relevant to the concepts being } \\
\text { studied. Learning sources that include the latest research } \\
\text { data which are contained in national or international } \\
\text { journals and the latest editions of books. }\end{array}$ \\
\hline 3 & Colleagues or others & $\begin{array}{l}\text { In capturing information from peers, it is necessary to } \\
\text { look at the experiences of friends in learning and need to } \\
\text { check / compare from several other sources so that there } \\
\text { is a comparison of the information read and can find / } \\
\text { provide the correct conclusions. }\end{array}$ \\
\hline 4 & $\begin{array}{l}\text { Initial conceptual under- } \\
\text { standing }\end{array}$ & $\begin{array}{l}\text { To overcome the initial misunderstanding, you must read } \\
\text { a lot from various relevant sources and there is a need for } \\
\text { proof in the form of practice, research, and case studies, } \\
\text { or other so that it can correct the initial understanding } \\
\text { that was wrong. }\end{array}$ \\
\hline
\end{tabular}

\section{Discussion}

From the research data above, it can be seen that there are quite a lot of student misconceptions on the concept of health biotechnology. Where the overall total of students who experience misconceptions on the concept of health biotechnology is $39.11 \%$. In addition, the data for each material indicator shows that students' misconceptions on the health biotechnology definition indicators were found to be $36.20 \%$, on indicators of types of health biotechnology which included types, techniques, stages, health biotechnology processes, student misconceptions were obtained by $34.86 \%$. On the indicators of health biotechnology benefits / advantages student misconceptions amounted to $46.26 \%$. This is supported by interview data as stated above, from the three material indicators, it shows that students experience misconceptions on the concept of monoclonal antibodies, health biotechnology techniques, recombinant vaccines, and human papilloma virus vaccines.

Interview data revealed that the causes of this misconception came from books, printed journals, and also other social media such as the internet, teaching staff, and 
colleagues, besides that many students also answered that the cause of the misconception was that biotechnology material was quite difficult because there was a connection with basic biological material that was abstract, many foreign terms that make it difficult for students to understand. This is supported by several theories as expressed by Barke et al. (2009) that misconceptions in students can be caused by various factors, such as teacher teaching, textbooks, and the learning methods used. Submission of information that is unclear and incomplete received by students in the learning process is also suspected as the cause of misconceptions. Even inaccurate selection of teaching strategies, for example, the use of inappropriate analogies, can also interfere with students' thought processes and have difficulty understanding the concepts being learned (Harini, 2014). Chrzanowski et al. (2018) also revealed that misconceptions on vernacular concepts arise when students experience problems with the use of certain scientific language phrases and they may appear in people of all ages, professions, and backgrounds. Kurniati et al. (2015) revealed that the inhibiting factor in learning is that the teacher still has difficulties in delivering material and assessment. In addition, it was also revealed by Awang (2015) that there are teachers who have a less pleasant teaching style and do not motivate students in learning.

The results of this study prove that the identification of health biotechnology misconceptions has a significant relationship with student learning outcomes. The identification of misconceptions carried out in this study provides an overview of the material with the most misconceptions. The effort to overcome the high misconceptions is by applying active learning to students. However, some of the mistakes made by teachers / lecturers in learning are not mistakes caused by misunderstandings, but may be due to inappropriate or careless use of terminology, such as in the context of monoclonal antibodies, health biotechnology techniques, recombinant vaccines, and human papilloma virus vaccines.

According to Duda (2016) that misconceptions experienced by students can occur due to misinterpreting natural phenomena or events in their life. The misconceptions that students had when 4 they were at school were still living with them until they were in college. Misconceptions usually develop along with the learning process. According to Chiu (2005) misconceptions can be caused by internal factors and external factors. Internal factors that cause student misconceptions can come from students' daily experiences, while external factors can come from textbooks, the learning process, learning media, and language. Students are not used to using their reasoning power, but are used to memorizing rather than understanding concepts correctly in the subject matter (Haryono, 2013, p. 2). Louga et al. (2013) revealed that advanced students have significant learning deficiencies at the conceptual level. In order for students to have a consistent and correct conceptual understanding, they must be able to develop a meaningful understanding of the concept.

In an attempt to present complex ideas in a simplified way according to the level of the student. Teachers and textbooks often use imprecise terms or statements that are open to different interpretations. Without in-depth presentation of existing topics, students are 
often misled by these terms or statements and develop conceptual errors. To avoid this, teachers should be trained to use textbooks more critically and selectively, and beware of inaccurate information described in textbooks (Din-yan Yip, 1998). Research by Firdaus \& Samsuri (2018) suggests that to change students' misconceptions about evolution through a better learning process, and of course also must be supported by resources (books, handouts) that can be used as guides or guidelines by students to understand and apply his understanding of evolution.

According to Din-yan Yip (1998) to be effective in correcting teacher misunderstandings and preventing them from spreading to students, teacher education programs should aim to improve/develop the knowledge and skills of biology teachers with the following strategies: first, what science educators find about science students' misconceptions: knowledge this helps teachers to develop awareness and understanding of the nature and sources of student misunderstandings, which is the first step in designing appropriate learning strategies. Second, methods for diagnosing misconceptions experienced by students before and after instruction: this information allows teachers to evaluate students' learning problems, which will provide continuous feedback on the effectiveness of the teaching methods used. Third, designing learning strategies that address student preconceptions and misconceptions: this involves planning and structuring curriculum materials and learning activities using a constructivist approach that aims to promote conceptual change and development, such as the use of examples and analogies, cognitive conflicts, concept maps, demonstrations, and student activities (Hashweh, 1996). Fourth, reviewing certain parts of the subject matter where the teacher has problems understanding concepts: given the fact that many practice teachers demonstrate the same conceptual errors as upper level students, they tend to do so to be a direct source of student misunderstanding. Many of these teacher misconceptions may have developed in schools and remained unmodified during subsequent studies. Since mastery of subject matter knowledge is a prerequisite for competent and effective teachers, teachers must attend training courses so as to provide teachers with a refreshing learning experience and consolidate their understanding of certain difficult concepts from the school curriculum.

\section{Conclusion}

Based on the results of research and theoretical analysis, it can be concluded that there are still many students who experience misconceptions both on each indicator of the health biotechnology sub-material under study or as a whole on the health biotechnology material, where $39.11 \%$ of students experience misconceptions. Misconceptions of health biotechnology concepts are the concept of monoclonal antibodies, health biotechnology techniques, recombinant vaccines, human papilloma virus vaccines. The factors that cause this misconception are in addition to difficult, abstract, and many foreign terms, 
the concept of health biotechnology is also caused by misconceptions in print media such as books or print journals, online media, teaching staff (teachers or lecturers), peers, or other environmental factors. The solution given to overcome these misconceptions is the use of appropriate teaching and learning strategies, using reliable learning resources, lecturers always reviewing concepts that often experience misconceptions.

\section{Suggestion}

For the teaching staff or further researchers, it is better if it is necessary to carry out misconceptions research on other sub-concepts of biology and also other sciences, because it is important for the teaching staff to find out student misunderstandings of the concepts in the science they are learning, and also be able to find out the factors- the factors causing the misconception. So that solutions can be given to overcome these misconceptions and will not have an impact on the learning process and the application of this knowledge.

Thank you:

For DRPM, the Directorate General of Research and Development Strengthening, the Indonesian Ministry of Research, Technology and Higher Education which has supported funds for research. For STKIP Persada Khatulistiwa Sintang, West Kalimantan, Indonesia which has provided facilities for research activities on the campus. For LPPM STKIP Persada Khatulistiwa Sintang, West Kalimantan, Indonesia, which has facilitated and launched research activities.

\section{References}

Artdej, R., Ratanaroutai, T., \& Coll, R. K. (2010). Thai grade 11 students' alternative conceptions for acid-base chemistry. Research in Science \& Technological Education, 28(2), 167-183. doi:10.1080/02635141003748382

Ayas, A., Ozmen, H., \& Calik, M. (2010). Students' conceptions of the particulate nature of matter at secondary and tertiary level. International Journal of Science and Mathematics Education, 8(1), 165-184. doi:10.1007/s10763-009-9167-x

Awang, I. S. (2015). Kesulitan belajar IPA peserta didik sekolah dasar [Difficulties in learning science for elementary school students]. Vox Edukasi [Vox Education], 6(2), 108-122.

Barke, H. D., Hazari, A., \& Yitbarek, S. (2009). Students' misconceptions and how to overcome them. In Misconceptions in chemistry (pp. 21-36). Berlin, Heidelberg: Springer.

Chiu, M. H. (2005). A National survey of student's conceptions in chemistry in Taiwan. Chemical Education International, (Online), 6 (1), 1-8. 
Chrzanowski, M. M., Grajkowski, W., Uchowski, S., Spalik, K. E., \& Ostrowska, B. (2018). Vernacular misconceptions in teaching science-types and causes. Journal of Turkish Science Education, 15(4), 29-54.

Din-yan Yip. (1998). Identification of misconceptions in novice biology teachers and remedial strategies for improving biology learning. International Journal of Science Education, 20(4), 461-477.

Duda, H. J. (2016) Analysis of genetic misconceptions student biology education at STKIP Persada Khatulistiwa Sintang. International Conference on Education, Education in the 21th Century: Responding to Current Issues, Graduate School. State University of Malang.

Firdaus, L. \& Samsuri, T. (2018). Kajian miskonsepsi mahasiswa pendidikan biologi FPMIPA IKIP Mataram tentang evolusi [Study of misconceptions by biology education students of FPMIPA IKIP Mataram about evolution]. Bioscientist : Jurnal Ilmiah Biologi [Bioscientist : Scientific Journal of Biology], 6(2), 122-129.

Gardner A. L. (2009). The biology teacher's handbook. USA: NSTA Press.

Hammer, D. (1996). More than misconceptions: multiple perspectives on student knowledge and reasoning, and an appropriate role for education research. American Journal of Physics, 64, 1316-1325.

Harini, L. P. I., Astawa I. G. S., \& Srinadi. I. G. A. M. (2014). Eksplorasi miskonsepsi mahasiswa dalam pengembangan buku teks analisis real bermuatan peta pikiran [Exploration of student misconceptions in the development of a real analysis textbook containing mind maps]. Seminar Nasional Sains dan Teknologi 2014. Denpasar - Bali, 18-19 September 2014. [National Seminar on Science and Technology 2014. Denpasar - Bali, 18-19 September 2014].

Haryono. (2013). Pengaruh media video terhadap peningkatan pemahaman konsep biologi siswa kelas XI SMK Negeri 1 Kalibagor [The effect of video media on increasing the understanding of biology concepts for class XI students of SMK Negeri 1 Kalibagor]. Tesis pada Universitas Muhammadiyah Purwokerto [Thesis at the University of Muhammadiyah Purwokerto]. Purwokerto.

Kirbulut, Z. D. (2014). Using three-tier diagnostic test to assess students' misconceptions of states of matter. Eurasia Journal of Mathematics, Science \& Technology Education, 10(5), 509-521.

Kurniati, A., Subekti, M. R \& Vera, M. O. 2021. Analisis peranan guru kelas dalam mengelola pembelajaran melalui kurikulum 2013 siswa kelas V SDN 17 Mungguk Kecamatan Sekadau Hilir tahun pelajaran 2020/202 [Analysis of the role of classroom teachers in managing learning through the 2013 curriculum for fifth grade students at SDN 17 Mungguk, Sekadau Hilir District, for the 2020/202 Academic Year]. Jurnal Pendidikan Dasar Perkhasa [Journal of Perkhasa Basic Education], 7 (1), 13-247.

Luoga, N. E., Ndunguru, A. P., \& Mkoma, L. S. (2013). High school students' misconceptions about colligative properties in chemistry. Tanzania Journal of Natural \& Applied Sciences, $4(1), 575-581$.

Muri, Y. (2017). Metode Penelitian: Kuantitatif, Kualitatif dan Penelitian Gabungan [Research Methods: Quantitative, Qualitative and Combined Research]. Jakarta: Perseroan terbatas Fajar Interpratama Mandiri [Limited company Fajar Interpratama Mandiri]. 
Murni, D. (2013). Identifikasi miskonsepsi mahasiswa pada konsep substansi genetika menggunakan Certainty Of Response Index (CRI). [Identification of student misconceptions on the concept of genetic substance using the Certainty Of Response Index (CRI)]. Prosiding Seminar [Seminar Proceedings]. Lampung: Faculty of Mathematics and Natural Sciences : University of Lampung.

Nusantari, E. (2011). Analisis dan penyebab miskonsepsi pada materi genetika buku SMA Kelas XII. [Analysis and causes of misconceptions in the genetic material of class XII high school books]. Bioedukasi [Bioeducation], 4(2), 72-85.

Purba, J. P. \& Depari, G. (2008). Penelusuran miskonsepsi mahasiswa tentang konsep dalam rangkaian listrik menggunakan Certainty of Response Index (CRI) dan interview [Searching students' misconceptions about concepts in electrical circuits using the Certainty of Response Index (CRI) and interviews]. Artikel penelitian pada Fakultas Pendidikan Teknologi dan Kejuruan UPI Bandung: tidak diterbitkan [Research article at the Faculty of Technology and Vocational Education, Indonesian University of Education Bandung: unpublished].

Puspitasari. Y., Reza. S. P. K., Bachtiar. Y., \& Prayitno, B. A. (2019). Identifikasi miskonsepsi materi jaringan tumbuhan pada mahasiswa pendidikan biologi di salah satu universitas di surakarta [Identification of misconceptions about plant tissue material in biology education students at a university in Surakarta] BIOEDUKASI Jurnal Pendidikan Biologi [BIOEDUCATION Journal of Biological Education], 10(2), 171-178.

Queloz, A. C., Klymkowsky, M. W., Stern, E., Hafen, E., \& Köhler, K. (2017). Diagnostic of students' misconceptions using the biological concepts instrument (BCI): a method for conducting an educational needs assessment. PLOS ONE. 12(5), e0176906. https://doi.org/10.1371/journal. pone.0176906 |https://doi.org/10.1371/journal.pone.0176906

Saehana, S. \& Kasim, S. (2011). Studi awal miskonsepsi mekanika pada guru fisika SMA di Kota Palu Initial study of misconceptions of mechanics in high school physics teachers in Palu City] Makalah dipresentasikan pada Seminar Nasional Penelitian, Pendidikan, dan Penerapan MIPA [Paper presented at the National Seminar on Research, Education, and Application of Mathematics and Natural Sciences. Universitas Negeri Yogyakarta [Yogyakarta State University].

Suniati, N. M. S., Sadia, W., \& Suhandana, A. (2013). Pengaruh implementasi pembelajaran kontekstual berbantuan multimedia interaktif terhadap penurunan miskonsepsi (Studi kuasi eksperimen dalam pembelajaran cahaya dan alat optik di SMP Negeri 2 Amlapura). [The effect of implementing interactive multimedia-assisted contextual learning on reducing misconceptions (a quasi-experimental study in learning light and optical instruments at SMP Negeri 2 Amlapura]. E-Journal Program Pascasarjana Universitas Pendidikan Ganesha [Ganesha University of Education Graduate Program E-Journal], 4(1), 1-13.

Susanti, R. (2018). Misconception of biology education student of teacher training and education of Sriwijaya University to the concept of photosynthesis and respiration. Journal of Physics: Conference Series, 1022. 012056. doi:10.1088/1742-6596/1022/1/012056 


\title{
Klaidingi studentų supratimai apie biologijos ugdymą: sveikatos biotechnologija
}

\author{
Hilarius Jago Duda ${ }^{1}$, Dwi Cahyadi Wibowo ${ }^{2}$, F. Rahayu Esti Wahyuni ${ }^{3}$, Antonius Edy Setyawan ${ }^{4}$, \\ Muhammad Rian Subekti ${ }^{5}$
}

1 Aukštoji mokytojų rengimo mokykla (STKIP), Persada Khatulistiwa, Biologijos mokymo studijų programa, JL. Pertamina-Sengkuangas, Sintangas, Vakarų Kalimantanas, Indonezija, hilariusjagod@yahoo.com

2 Aukštoji mokytojų rengimo mokykla (STKIP), Persada Khatulistiwa, Pradinių klasių mokytoju rengimo studiju programa, JL. Pertamina-Sengkuangas, Sintangas, Vakarų Kalimantanas, Indonezija, dwicahyadiwibowo@gmail.com

3 Aukštoji mokytojų rengimo mokykla (STKIP), Persada Khatulistiwa, Biologijos švietimo studijų programa, JL. Pertamina-Sengkuangas, Sintangas, Vakarų Kalimantanas, Indonezija, estipandi84@gmail.com

4 Aukštoji mokytojų rengimo mokykla (STKIP), Persada Khatulistiwa, IT technologiju mokymo programa. PertaminaSengkuangas, Sintangas, Vakarų Kalimantanas, Indonezija, edysetyawan200286@gmail.com

5 Aukštoji mokytojų rengimo mokykla (STKIP), Persada Khatulistiwa, Pradinių klasių mokytojų rengimo studijų programa. Pertamina-Sengkuangas, Sintangas, Vakarų Kalimantanas, Indonezija. m.rian.subekti@gmail.com

\section{Santrauka}

Klaidinga studentų nuomonė yra pagrindinè švietimo problema, mokantis ịvairių dalykų, taip pat ir biotechnologijų. Mokslininkai bando įvertinti klaidingas sampratas apie sveikatos biotechnologijos sąvoką (ypač antikūnių ir vakcinų srityje), kylančias studentams, studijuojantiems / studijavusiems biotechnologijų kursuose. Tyrimo prieiga yra kokybinè, o naudojamas tyrimo metodas - aprašomasis kokybinis. Tiriamąją populiaciją sudare Indonezijos biologijos mokymo programos (STKIP Persada Khatulistiwa Sintango) studentai; imtis 29 biotechnologijas studijavę studentai. Pasitelkiant kartotinị diagnostinị testą buvo taikomi duomenų rinkimo metodai ir interviu. Duomenų analizė apdorota pagal atsakymų tikrumo indeksą aprašomuoju būdu. Gauti rezultatai rodo, kad neteisingai suvokiama sveikatos biotechnologijos samprata sudaro 39,11 proc.

Interviu rezultatai rodo, kad studentai neteisingai suprato monokloninių antikūnių sampratą, sveikatos biotechnologijų metodus, rekombinantines vakcinas ir žmogaus papilomos viruso vakcinas. Veiksniai, lemiantys studentų klaidingą nuomonę, yra abstrakčios sąvokos, taip pat daugelis užsienio kalbų terminų, informacija iš spausdintos žiniasklaidos, interneto, dèstytojų ir kolegų. Siekiant suformuoti teisingą nuomonę, reikalingas tinkamas mokymo ir mokymosi strategijų naudojimas, patikimi mokymosi šaltiniai, dėstytojams visada reikètų peržiūrèti sąvokas, kurios dažnai turi ịtakos klaidingai nuomonei, o studentams reikètų kuo daugiau skaityti šios srities literatūros.

Esminiai žodžiai: klaidingi supratimai, studentai, sveikatos biotechnologijos, Indonezija. 